\title{
Ulike tjenestetilbud for homofile og lesbiske
}

\section{Rådgivningstjenesten for homofile og} lesbiske

Grensen 5-7, 0159 Oslo. T If. 22082950

Rådgivningstjenesten er et psykologtilbud i Oslo. Tjenesten består av fire psykologer to kvinner og to menn som alle er lesbiske/ homofile. Dette er et tilbud rettet primært mot deg som har et behov for samtaler med utgangspunkt i seksuell identitet, seksualitet og legning. Det er også et tilbud til deg som opplever det vanskelig å snakke om dette med andre i hjelpeapparatet eller opplever å ikke bli forstått når temaer rundt legning og seksualitet kommer opp.

Du kan ikke møte opp uten avtalt time.

Helseutvalget for lesbiske og homofile

Besøksadr.: Kongens gate 12

Postadr.: Postboks 1004, Sentrum 0104 Oslo

TIf. 23357200 Telefaks: 23357201

E-post: post@helseutvalget.no

Denne landsdekkende organisasjonen har et samtale- og veiledningstilbud for lesbiske, bifile og homofile. I tillegg kan man delta på grupper eller seminarer som fokuserer på ulike sider ved det å leve som lesbisk, homofil, bifil eller skeiv.

Helseutvalget skal, med utgangspunkt i aktuelle helsespørsmål, drive helsefremmende og forebyggende arbeid. Se Angeltvedts artikkel (s 14 ff) for mer informasjon.

\section{Klinikk for seksuell opplysning}

Trondheimsveien 2, bygg B, 0560 Oslo

T If. $2299 \mathbf{3 9} \mathbf{0 0}$ mellom kl 09.00 og 15.00

Fire kvelder i uka, mandag til torsdag har

Klinikken åpent for gratis konsultasjoner

hovedsakelig for ungdom (jenter og gutter)

i aldersgruppa opp til 25 år. Da er tre leger og to sykepleiere på vakt fra kl 16-20. Trenger du hjelp med prevensjon, graviditet, abort, sjekk for seksuelt overførbare infeksjoner (SOI) eller har seksuelle problemer, kan du komme til Klinikken i åpningstiden.

Ingen timebestilling - kølappsystem.

På dagtid svarer vi på spørsmål i telefonen, stort sett fra kl 09.00-15.00.

\section{Olafiaklinikken}

Grensen 5-7, 0159 Oslo. T If. 22082950

Et senter for rådgivning, unders $\varnothing$ kelse og behandling av seksuelt overførbare infeksjoner og hiv. Dette tilbudet er også for kvinner som har sex med kvinner. Vi tilbyr også vaksinasjon og reisemedisin. D rop In - Ingen timebestilling! Åpningstid: Mandag: kl. 11.45 til kl. 17.00* Tirsdag til fredag: kl. 07.45 til kl. 11.00*

* tidspunkt for stenging er avhengig av antall pasienter.

\section{Brynsenglegene}

Brynsengv. 2, 0667 Oslo. T If. 22727868 Kveldsåpent helsetilbud for menn som har sex med menn. Test, rådgivnings- og behandlingstilbudet på Brynseng har åpent onsdager fra k1.16.00 - 21.00. Tilbudet er gratis. Du kan enten bestille time eller møte opp.

Andre test- og behandlingstilbud for seksuelt overførbare sykdommer for menn som har sex med menn og kvinner som har sex med kvinner

\section{Drammen}

St. Josef hospital. T If. $\mathbf{3 2} \mathbf{8 0} \mathbf{8 4} \mathbf{8 0}$

\section{Fredrikstad}

Sykehuset Østfold, Infeksjonsmedisinsk poliklinikk. Telefon: 69367100

\section{Kristiansand}

Sentrum legesenter. T If. $\mathbf{3 8} \mathbf{0 7} \mathbf{9 0} 00$

\section{Stavanger}

Stavanger Universitetssjukehus,

Medisinsk poliklinikk. TIf. 51519427

Bergen

Haukeland Universitetssykehus, Hudpoliklinikken. T If. 55973960

Trondheim

St Olavs hospital, Hud- og venerisk poliklinikk. T If. 73868940

Nicolaisen legekontor.

Telefon: 73525620

Troms $\varnothing$

Sosialmedisinsk senter. T If. $77 \mathbf{6 0} \mathbf{4 9} \mathbf{5 0}$ 